\title{
Hermeneutyka dyskursu w ujęciu Fritza Hermannsa
}

\author{
Discourse Hermeneutics in Fritz Hermanns' Approach
}

\begin{abstract}
Linguistic meanings function in a specific social reality. According to Fritz Hermanns, knowledge about this reality is an integral part of semantic knowledge, which includes three aspects of human communicative actions: cognitions, emotions and intentions, understood as cognitive, affective and volitive dispositions of a collective. From this perspective, the discourse may be reduced to the entirety of knowledge actualized in communication practices belonging to a given discursive formation, while the task of discourse hermeneutics is to explain how mutual cognitions, emotions and intentions of various social groups manifest themselves in individual utterances, and vice versa: how collective thinking, feeling and wanting change existing linguistic conventions.
\end{abstract}

Key words: linguistic hermeneutics, discourse analysis, descriptive meaning, emotional meaning, deontic meaning

\begin{abstract}
Abstrakt: Znaczenia językowe funkcjonują w konkretnej rzeczywistości społecznej. Wiedza o tej rzeczywistości jest - zdaniem Fritza Hermannsa - integralną częścią wiedzy semantycznej, która obejmuje trzy aspekty ludzkich działań językowych: kognicje, emocje i intencje, rozumiane jako kolektywne dyspozycje kognitywne, afektywne i wolitywne. Dyskurs z tej perspektywy sprowadza się do całokształtu wiedzy aktualizowanej w praktykach komunikacyjnych, należących do danej formacji dyskursywnej, natomiast zadaniem hermeneutyki dyskursu jest wyjaśnienie, jak manifestują się $w$ poszczególnych wypowiedziach społecznie dzielone kognicje, emocje i intencje różnych grup społecznych, i odwrotnie: jak różne formy kolektywnego myślenia, odczuwania i chcenia zmieniają istniejące konwencje językowe.
\end{abstract}

Słowa kluczowe: hermeneutyka lingwistyczna, analiza dyskursu, znaczenie deskryptywne, znaczenie emocjonalne, znaczenie deontyczne

\section{Wstęp}

Z nazwiskiem Fritza Hermannsa wiąże się kilka interdyscyplinarnych programów badawczych, na przykład: antropologia lingwistyczna (HermanNs, 1994), semantyka polityczna (Hermanns, 1996; 2003; 2005), lingwistyka kulturoznawcza (Hermanns, 1993a; 1993b; 1995b; 1995c; 1999) czy też hermeneutyka lingwistyczna (HERmAnNs, 2003; 2007a). Na potrzeby tych programów Hermanns stworzył własną koncepcję holistycznej analizy wypowiedzi językowych, która nawiązuje do Bühlerowskich funkcji znaku. W swojej koncepcji Hermanns (1995a) sprowadza analizę potrójnej funkcji użycia języka (przedstawiania, wy- 
rażania i apelowania) do analizy kognicji, emocji i woli jego użytkowników ${ }^{1}$. Proponuje też połączenie tych trzech aspektów działań językowych w pojęciu mentalności (Hermanns, 1995a), by w końcu (Hermanns, 2002a) sprowadzić tę triadę do kategorii nastawienia (Einstellung), która obok nastawienia propozycjonalnego (kognicji, świadomości czy wiedzy) obejmuje także nastawienie emocjonalne i motywację mówców/odbiorców.

W dalszej części opracowania zostaną wykazane główne zalety stworzonej przez Hermannsa triadycznej koncepcji znaczenia z punktu widzenia pragmatyki językowej. Podjęta zostanie także refleksja nad możliwościami zastosowania tej koncepcji $w$ deskryptywnej analizie dyskursu.

\section{Podstawowe założenia hermeneutyki lingwistycznej}

Hermeneutyka lingwistyczna jest stosunkowo nową, ale intensywnie rozwijającą się dziedziną językoznawstwa, zwłaszcza językoznawstwa germańskiego. Hermanns (2003: 125) określa ją jako „mocną kartę” lingwistyki i wyjaśnia jej kluczową rolę następująco: Działania językowe, jeśli nie zostaną zinterpretowane, nie spełnią żadnej ze swoich funkcji (por. Hermanns, 2003: 125). Również na poziomie metajęzykowym każda analiza teoretyczna bazuje na pewnej interpretacji danych językowych. Analiza dyskursu nie jest pod tym względem wyjątkiem, zwłaszcza gdy bada i opisuje funkcje społeczne działań językowych, a nie tylko warunki czy reguły użycia języka.

Zasadniczo każda interpretacja danych językowych jest dostępna bezpośrednio tylko podmiotowi interpretującemu. Znaczenie językowe nie jest dane a priori, nie jest też immanentną cechą działań językowych, znaków czy symboli. Nie jest ani ukryte, ani zakodowane $w$ użytych $w$ danej wypowiedzi wyrażeniach językowych (por. ZıEM, 2008: 158-159). Wypowiedzi to tylko „zewnętrzne bodźce” (SCHERnER, 1984: 71), czyli sygnały, które wywołują $w$ umyśle określone procesy myślowe, tj. procesy interpretacyjne prowadzące do zrozumienia danej wypowiedzi².

Znaczenie, chociaż istnieje tylko $w$ procesie interpretacji (i $w$ tym sensie nie jest faktem obiektywnym, lecz co najwyżej intersubiektywnym), nie jest jednak nadawane przez podmiot interpretujący każdorazowo „od nowa”. Stanowi wynik wysoce zindywidualizowanych procesów inferencyjnych (analizowania, kojarzenia, wnioskowania), ale jest tworzone na podstawie konwencji językowo-kulturowych przyswojonych dzięki socjalizacji ${ }^{3}$. Konwencje

${ }^{1}$ Kognicje, czyli myśli lub treści pomyślane, odpowiadają logosowi w klasycznym podziale funkcji wypowiedzi; emocje - patosowi; wola, czyli intencje - etosowi.

${ }^{2}$ Różne warianty interpretacyjne tych samych wypowiedzi są empirycznym potwierdzeniem indeksykalności używanych w komunikacji znaków. Powszechnie przyjmowana symboliczna funkcja języka jest wtórna w stosunku do indeksykalnej, gdyż stanowi wynik przypisania znakom językowym określonego potencjału semantycznego uśrednionego na podstawie pewnego spektrum możliwości interpretacyjnych.

3 „Proces interpretacji jest więc twórczy o tyle, o ile jest aktywnością własną odbiorcy aktualizującego i dostosowującego do kontekstu nabyte przez socjalizację konwencje. Nie jest on natomiast twórczością $w$ sensie tworzenia samych konwencji, które istnieją w świadomości społecznej i są względnie niezależne od pojedynczych aktów użycia języka" (TopczewsKA, 2011: 192). 
te są częścią wiedzy dzielonej społecznie, tj. wiedzy wspólnej danej grupy społecznej. Budowane na ich podstawie znaczenia mogą być przedmiotem badań na poziomie systemu językowego, a więc na gruncie semantyki leksykalnej, oraz - a według Hermannsa przede wszystkim - jako „znaczenia w użyciu”, czyli znaczenia w kontekście czy też znaczenia dyskursywne.

Hermanns (2007a) uważa, że lingwistyczna analiza dyskursu w ujęciu hermeneutycznym nie jest dyscypliną eksperymentalną, badającą reguły działań językowych, lecz jest dyscypliną interpretatywną, badającą znaczenia tychże działań. Z tego punktu widzenia powiązania metodologiczne hermeneutyki i analizy dyskursu wydają się ewidentne, nawet jeśli sama lingwistyka raczej odcina się od tradycji hermeneutycznej. Obydwie dziedziny bazują jednak na interpretacji wypowiedzi językowych (werbalnych i niewerbalnych), które jako sygnały komunikacyjne mają charakter indeksykalny, niepełny, „szkicowy” (Levinson, 2000)4. Obydwie dążą też do możliwie pełnej eksplikacji znaczenia wypowiedzi, przy czym w przypadku analizy dyskursu eksplikacja obejmować będzie obok treści propozycjonalnych także treści niepropozycjonalne (nieoparte na pojęciach), których wartość epistemiczną wyraża ich odniesienie do przyjętej $w$ danej wspólnocie językowej normy (np. etycznej, estetycznej czy jakościowej) $)^{5}$. Zbadanie wiedzy o tych normach i poznanie ich zasięgu społecznego należy do deklarowanych celów postfoucaultowskiej analizy dyskursu (por. np. SPitzmüLler, Warnke, 2011).

Metoda hermeneutyczna $w$ analizie dyskursu opiera się na tej samej zasadzie, co rozumienie zjawisk językowych $w$ codziennych praktykach komunikacyjnych, tj. na empatii. Empatia jest rozumiana przez Hermannsa (2007b) jako zdolność wglądu w uczucia, ale także w kognicje i intencje innych osób. Uczucia są oczywiście domeną empatii, lecz dojrzała empatia dotyczy również rozumienia myśli drugiej osoby i jej dążeń (por. HermanNs, 2007b: 135) ${ }^{6}$. Hermanns, przedstawiając swoją metodę, wielokrotnie podkreśla istotny dla

${ }^{4} \mathrm{~W}$ procesie interpretacji odbieranych sygnałów następuje uzupełnienie czy też semantyczne wzbogacenie informacji wynikających bezpośrednio z danej wypowiedzi (por. LıEDTKE, 2007).

${ }^{5}$ Treści niepropozycjonalne nie są zatem uwzględniane w tradycyjnej semantyce, gdyż nie podlegają kategoriom analitycznym prawdziwe/fałszywe.

${ }^{6}$ Inaczej postrzega rolę empatii $w$ hermeneutyce amerykański etnolog Clifford Geertz, zwany „ojcem nowoczesnej interpretatywnej antropologii kulturowej” (ВАснмANN-MEDıcк, 2012: 66), który wprowadził metodę hermeneutyczną do nauk społecznych, postulując interpretację obserwowanych zjawisk (studium przypadku) w miejsce wyjaśniania ich struktur i funkcji. GeERTz (2005) uważa, że aby opisać kulturowy wymiar zjawisk społecznych (działań, znaków i symboli) i wyjaśnić ich znaczenie „lokalne” (tj. w danym kontekście, a nie w systemie), nie ma potrzeby odwoływania się do empatii, gdyż znaczenie nie powstaje $w$ głowach jednostek, lecz w relacjach społecznych, i jest kategorią szerszą niż „to, co autor miał na myśli”. Analiza społecznego procesu konstytuowania znaczeń wymaga zatem nie empatii (jak np. w metodzie obserwacji uczestniczącej), lecz kontekstualizacji działań, znaków i symboli w świadomości społecznej. Postulowana przez Geertza metoda interpretacji opiera się na obserwacji tego, co obserwują inni. Ponieważ tzw. dane empiryczne to „konstrukty na temat konstruktów innych" (GEERTz, 2005), żeby je zinterpretować, należy najpierw zrozumieć interpretacje innych - nie odczuć, lecz zrozumieć, czyli - według Geertza - osadzić w kontekście społecznym i przyjmując różne perspektywy interpretacyjne, odkrywać kolejne warstwy znaczeniowe. Tę metodę analizy Geertz nazywa, za Gilbertem Ryle’em (1971), „opisem gęstym” lub symbolicznym konstruktywizmem. 
hermeneutyki lingwistycznej fakt, że rozumienie wypowiedzi językowych to proces, w którym odgrywa rolę czynnik epistemiczny łącznie z emotywnym i wolitywnym. Kognicje, emocje i intencje należą do tych czynników komunikacji, dzięki którym staje się ona komunikacją ludzką. Wyraża się w nich zarówno indywidualna tożsamość użytkownika języka, jak i jego tożsamość kulturowa uwarunkowana przynależnością do określonych grup społecznych. Wszystkie trzy czynniki winny zatem, zdaniem Hermannsa, zostać uwzględnione $w$ analizie językoznawczej: przede wszystkim $w$ badaniach analityczno-dyskursywnych, ale także $w$ analizie leksykologicznej.

\section{Kognicje, emocje, intencje}

Punktem wyjścia jest dla Hermannsa wspomniany już fakt, że za pomocą języka można dokonać znacznie więcej, niż sformułować i wyrazić treści propozycjonalne. W wypowiedziach językowych obok myśli (kognicji, rozumianych jako konceptualizacje stanów rzeczy) wyrażane są także emocje i intencje $\mathrm{e}^{7}$.

Semantyzacja i leksykalizacja kognicji jest faktem bezspornym. Hermanns podkreśla jednak, że również emocje i intencje mogą zostać zleksykalizowane. Jako przykład podaje leksykalizację emocji w wykrzyknieniu pfui ${ }^{8}$, które oznacza wstręt (Ekel), ale jednocześnie wyraża to uczucie (por. HermanNs, 1995a: 146) ${ }^{9}$. Emocje są zleksykalizowane także w zdrobnieniach i zgrubieniach, w wulgaryzmach oraz $w$ leksemach nacechowanych afektywnie, takich jak miły, wspaniały, niesamowity, skarb, potwór itp., których prymarną funkcją jest wyrażanie emocji, a nie ich nazywanie. Zleksykalizowane intencje Hermanns identyfikuje natomiast $w$ tzw. leksemach deontycznych, które nie tylko nazywają stany rzeczy, ale też sygnalizują, co powinno się z nimi robić, na przykład praca ('należy wykonać'), środowisko ('należy chronić'), matka ('należy szanować'), czynsz ('należy zapłacić'), zielsko ('należy wyrwać'). Jeśli zielsko nazwiemy kwiatkiem, inna nazwa będzie sygnalizowała nie tylko zmianę naszego sposobu postrzegania danego obiektu, ale będzie także wyrażała zmianę naszego stosunku do niego - będziemy się z nim delikatniej obchodzić: nie będzie wyrwany, lecz co najwyżej zerwany. Wyrażające powinność znaczenie deontyczne jest także zgramatykalizowane $w$ łacińskich formach gerundivum (np. explicandum, definiendum) oraz zapożyczonych z łaciny morfemach -ent i -ant (np. abiturient, student, magistrant, doktorant).

${ }^{7}$ Emocje i intencje mogą być wyrażane $w$ formie propozycjonalnej, np.: Cieszę się, że..., Martwi mnie to, że..., Jest niedopuszczalne, by..., jednak według Hermannsa w przypadku takich wypowiedzi dokonuje się przede wszystkim nazywanie treści niepropozycjonalnych, które nie musi łączyć się z ich wyrażaniem. Mogą to być tylko formuły rutynowo użyte w celu osiągnięcia określonych efektów perlokucyjnych.

${ }^{8}$ Jego polskie odpowiedniki tfu, fu i fe mogą oznaczać także pogardę i potępienie (por. GruszCZYŃSKA, 2001: 146).

9 Również Maciej Grochowskı (1997: 15) przyznaje wykrzyknieniom funkcję wyrażania emocji, nie przyznaje tej funkcji jednak statusu znaczenia. Inaczej Anna WierzBıckA (1991: 289), która uznaje wykrzyknienia za jednostki mające własne znaczenie i dające się opisać za pomocą formuły „I feel something". 
Kognicje, emocje i intencje to według Hermannsa trzy podstawowe aspekty znaczenia, które określa on jako znaczenie kognitywne, znaczenie emotywne i znaczenie wolitywne (deontyczne) $^{10}$. Dopiero uwzględnienie wszystkich trzech aspektów zapewnia całościowe ujęcie procesu nadawania znaczenia, gdyż z reguły nazywanie kognicji łączy się z wyrażaniem emocji i sygnalizowaniem intencji ${ }^{11}$. Jedno poniekąd implikuje drugie ${ }^{12}$. Jako przykład HERMANNS (1995a: 140) analizuje następujące wołanie o pomoc:

\section{(1) Hilfe! $!^{13}$}

Z wypowiedzi (1) można wywnioskować, że jej nadawca znajduje się $w$ niebezpieczeństwie i ten aspekt znaczenia wypowiedzi Hermanns nazywa kognicją odnoszącą się do pewnego stanu rzeczy. W wołaniu o pomoc jest ona wyrażona implicytnie, eksplicytnie natomiast (1) wyraża strach mówcy (znaczenie emotywne) i jego wolę otrzymania pomocy (znaczenie deontyczne). Taka eksplikacja znaczenia emotywnego dowodzi, że Hermanns nie łączy go z wyrażeniami nazywającymi emocje $\mathrm{e}^{14}$. Znaczenie emotywne to kategoria semantyczna, która nie odnosi się do konceptualizacji emocji $w$ języku, lecz wskazuje na konstytutywną rolę emocji $w$ tworzeniu znaczeń. Podobnie znaczenia deontyczne przysługują nie tyle wyrażeniom nazywającym powinność (które $w$ pewnych przypadkach znaczenia tego mogą w ogóle nie posiadać), ile wyrażeniom „narzucającym” odbiorcy, co powinien wykonać, przy czym powinność odbiorcy jest zarazem wolą mówcy (por. Hermanns, 1995a: 155).

\section{Kognicje, emocje i intencje jako kolektywne formy wiedzy}

Kognicje, emocje i intencje pełnią $w$ procesie komunikacji, zdaniem Hermannsa, analogiczne funkcje, jak symbol, symptom i sygnał w Bühlerowskim modelu semiozy. Znaczenie kognitywne pełni funkcję symboliczną ${ }^{15}$, znaczenie emotywne - funkcję symptomatyczną,

${ }^{10} \mathrm{~W}$ semantyce leksykalnej znaczeniu kognitywnemu odpowiada znaczenie deskryptywne, znaczeniu emotywnemu - znaczenie ekspresywne, a znaczeniu deontycznemu - znaczenie preskryptywne (odnoszące się do powinności).

${ }^{11}$ Także eksperymenty psycholingwistyczne wskazują na to, że kognicje nie są autonomiczne względem emocji (por. SchWARz-FrIESEL, 2007). W psychologii rozwojowej istnieje nawet pogląd, że to inteligencja emocjonalna umożliwia proces myślenia.

12 „In aller Regel ist es so, daß eine ausgedrückte Emotion mit einer dargestellten Kognition und einer offenbarten Intention zusammenpasst, so daß man von dem einen auf das andere sogar schließen kann" (Hermanns 1995a: 144).

13 Pol.: Ratunku!

14 Wyrażenia wyrażające emocje mogą być użyte $w$ funkcji nazywania emocji, podobnie jak wyrażenia nazywające emocje (np. strach, szczęśliwy, kochać) mogą być użyte w funkcji ich wyrażania. Por. dyskusję na temat zdania Ich liebe dich w Hermanns (1995a: 145) i SchwArz-Friesel (2007: 147).

${ }^{15}$ Zdaniem Johna R. SeArle'A (2010) symboliczna funkcja języka jest podstawą istnienia wszystkich instytucji społecznych. Być może tym należałoby tłumaczyć uprzywilejowane miejsce tej funkcji $w$ badaniach językoznawczych, a nawet utożsamianie wiedzy symbolicznej z wiedzą językową tout court. 
znaczenie deontyczne z kolei - funkcję apelatywną. Karl Ludwig BüHLER (1934) odnosi te funkcje do znaków językowych w systemie, czyli do wyizolowanych jednostek leksykalnych, natomiast Hermanns (1995a) odnosi je do całych wypowiedzi i pokazuje, że Bühlerowski model znaku jest $w$ zasadzie modelem komunikacji: symptomatyczny wymiar znaku odnosi się do nadawcy, apelatywny - do odbiorcy, a symboliczny - do przedstawianej przez znak rzeczywistości (HermanNs, 1995a: 143).

Bühlerowski znak reprezentuje, według Hermannsa, działanie językowe, które występuje $w$ praktyce komunikacyjnej jako token, ale zarazem przedstawia pewien type wypowiedzi. W procesie percepcji działanie językowe zostaje zredukowane do tego, co jest relewantne dla danego typu zgodnie z Bühlerowską zasadą „abstrakcyjnej relewancji”, jednocześnie zaś $w$ procesie jego interpretacji brane są pod uwagę także te cechy wypowiedzi, o których skądinąd wiemy, że przysługują wypowiedziom tego typu - Bühler ujmuje to w swojej zasadzie „aperceptywnego uzupełnienia” (por. BüHLER, 1934: 28). Powraca ona w Grice'owskiej zasadzie kooperacji i podległych jej maksymach konwersacyjnych czy też w Levinsonowskich heurystykach, na których podstawie wypowiedzenia (what is said) są uzupełniane o znaczenie implikowane (what is mean) ${ }^{16}$.

W przykładzie (1) znaczenie implikowane to znaczenie kognitywne, częściej jednak znaczenie emotywne i/lub deontyczne jest tworzone inferencyjnie ze znaczenia kognitywnego (deskryptywnego) wypowiedzenia ${ }^{17}$. Zachodzące tu procesy inferencyjne Hermanns bada wprawdzie na poziomie leksykalnym, ale odwołując się do szerokiego kontekstu dyskursywnego. Perspektywa dyskursywna pozwala mu uwzględnić seryjność odnośnych wypowiedzi i tym samym przypisać badanym znaczeniom status wiedzy kolektywnej. Metoda hermeneutyczna stosowana przez Hermannsa zostanie omówiona w dalszej części wywodu na przykładzie analizy znaczenia deontycznego leksemu wojna.

Od 11 września 2001 roku społeczeństwo USA wiedziało, że znajduje się w stanie wojny z terroryzmem. Wielokrotnie powtarzana przez prezydenta George'a W. Busha i rozpowszechniana $w$ mediach deklaracja rozpoczęcia the war against terrorism, która początkowo (np. w pierwszym przemówieniu Busha wieczorem 11 września 2001 roku) mogła wydawać się metaforycznym określeniem woli zdecydowanego zwalczania terroryzmu, wkrótce znalazła swój konkretny wyraz w działaniach militarnych USA przeciw Irakowi i Afganistanowi,

16 Stephen C. Levinson (2000) zurócił uwagę na fakt, że uzupełnienie to ma charakter presumptywny (przejściowy, prowizoryczny) w tym sensie, że może być zawsze zmienione pod wpływem innych informacji. Jak zauważa HermanNs (2007a: 188), jest to fakt znany tradycji hermeneutycznej, gdyż już Friedrich Schleiermacher wyjaśniał proces interpretacji za pomocą terminu rozumienie przejściowe (niem. vorläufiges Verstehen).

${ }^{17}$ Znaczenie deontyczne zostało ujęte $w$ teorii aktów mowy jako illokucje i w tej kategorii jest też zwykle uwzględniane $w$ analizie dyskursu. Konstytutywna rola emocji $w$ procesie rozumienia jest natomiast zwykle pomijana $w$ lingwistycznym modelowaniu znaczenia wypowiedzi. Analiza emocji to z reguły leksykologiczna analiza przypadku, rozwijana często na marginesie analizy deskryptywnej. Przyczyny tego stanu rzeczy Monika Schwarz-Friesel (2007) upatruje w kartezjańskim obrazie człowieka, w myśl którego zakłada się rozdzielenie umysłu (myśli, kognicji) i emocji, i wbrew wynikom eksperymentów neurologicznych preferuje się scjentystyczne spojrzenie na ludzki umysł. Tymczasem w psychologii mówi się wprost, że inteligencja, która umożliwia proces myślenia, to inteligencja emocjonalna (por. SAlovey, MAYER, 1990). 
chociaż ani terroryzm, ani nawet terroryści nie są podmiotami prawa międzynarodowego, a więc asercja the war against terrorism nie może być prawdziwa. Wojna stała się faktem, po tym, jak Bin Laden i Saddam Hussein zostali uznani w świadomości społecznej Amerykanów za ucieleśnienie terroryzmu, a więc metonimiczne przesunięcie znaczenia terminu terroryzm usprawiedliwiło przed amerykańską i światową opinią publiczną konieczność podjęcia działań wojennych. Wiedzę społeczną o tym, że USA muszą prowadzić wojnę, usankcjonowało oświadczenie Busha z 20 września 2001 roku:

(2) On September the $11^{\text {th }}$, enemies of freedom committed an act of war against our country ${ }^{18}$.

Dopiero w kontekście tej wypowiedzi Busha wyrażenie the war against terrorism z 11 września 2001 roku zyskuje swoje pełne emocjonalne i deontyczne znaczenie, które Hermanns (2005: 161) streszcza $w$ formule „psychologiczne przygotowanie do wojny”. Warto zauważyć, że należy tu nie tylko analizowane przez Hermannsa wywołanie gotowości do poniesienia ofiar i do poświęceń ze strony społeczeństwa, ale także wytworzenie społecznej akceptacji dla działań wojennych, co można postrzegać jako ewaluatywną funkcję odpowiednich emocji ${ }^{19}$.

Hermanns (2005) zauważa jednak, że znaczenie poszczególnych wyrażeń jest tworzone i utrwalane nie tylko przez dyskursy, współcześnie zwłaszcza dyskursy medialne, ale także przez doświadczenia wspólnoty dyskursywnej. Doświadczenia związane z wojną w Ameryce są odmienne od europejskich. Społeczność USA jako mocarstwa przyzwyczajonego do zwycięstw (niem. sieggewohnte Weltmacht) wie, że konsekwencją wojny jest zwycięstwo i panowanie nad pokonanym. Z doświadczeń europejskich wynika, że wojna wiąże się przede wszystkim ze zniszczeniem kraju. Wynikająca z odmiennych doświadczeń odmienna wiedza o tym, czym jest wojna, implikuje odmienne emocje i gotowość do odmiennych działań. W Europie znaczenie deontyczne wojny można wyrazić formułą No war!, natomiast w USA: „Wojna musi być przeprowadzona energicznie i wygrana” (HermanNs, 2005: 163-164).

\section{Ku semantyce dyskursywnej}

Hermanns uważa, że o ile znaczenia kognitywne i wynikające z nich znaczenia emotywne mogą być opisywane $w$ ramach semantyki leksykalnej, o tyle znaczenia deontyczne można badać tylko $w$ kontekście dyskursywnym ze względu na ich silną zależność od historycznie zmiennych warunków życia społecznego. W zasadzie analiza semantyczna to zawsze analiza transtekstualna $w$ rozumieniu deskryptywnej analizy dyskursu, gdyż, jak

18 „11 września wrogowie pokoju dokonali aktu wojny względem naszego kraju” - cyt. za HERMANNS (2005: 160). Komentarz Hermannsa do tej wypowiedzi jest następujący: „Zatem USA w tym czasie już znajdowało się $w$ stanie wojny, podobnie jak w 1941 r. po ataku na Pearl Harbor - tym razem razem wojny z terroryzmem” [tłum. U.T.] („Demnach waren die USA zu diesem Zeitpunkt schon im Krieg, wie 1941 nach dem Angriff auf Pearl Harbor. Nunmehr »at war against terrorism«. Wie sie sich bis 1990 permanent im »Kalten Krieg« befunden hatten" - HERMANNS, 2005: 160).

${ }^{19} \mathrm{Na}$ temat tej funkcji emocji por. SchwARz-FrIESEl (2007: 72-76). 
pisze Hermanns (2007a: 203), tylko w dyskursach, a nie w wyizolowanych jednostkach leksykalnych, ujawniają się konwencje społeczne dotyczące zarówno kognicji, jak i emocji i intencji przekazywanych $w$ komunikacji językowej.

Dyskursy jako przedmiot badań lingwistycznej analizy dyskursu są korpusami tekstów, czyli produktami praktyk komunikacyjnych, zestawionymi do celów analizy według kryteriów tematycznych, czasowych i innych ${ }^{20}$. Analiza produktów działań językowych może rekursywnie prowadzić do identyfikacji abstrakcyjnych reguł użycia języka. Dyskursy jednak to przede wszystkim materialne świadectwa tego, jak ludzie myślą, czują i chcą. Pozwalają one uchwycić i wyjaśnić relacje między językiem a społeczeństwem. Według Hermannsa relacje te dotyczą kognicji, emocji i intencji, które konstytuują mentalność danego społeczeństwa (por. Hermanns, 1995b: 77), a szerzej rzecz ujmując - jego kulturę (por. Hermanns, 1999: 353-355). Indywidualne kognicje, emocje i intencje to z jednej strony wewnętrzne dyspozycje człowieka uzdalniające go do działań językowych, które Hermanns (2002b) ujmuje $w$ psychologicznej kategorii nastawienia, z drugiej strony utrwalone w dyskursach kognicje, emocje i intencje wyrażają przynależność społeczną i kulturową danej jednostki ${ }^{21}$. Natomiast lingwistycznie wyabstrahowane znaczenia kognitywne, emocjonalne i deontyczne utrwalone $w$ danej wspólnocie dyskursywnej można uznać za aspekty mentalności społecznej. Lingwistyka, także lingwistyka dyskursywna, nie wyjaśni zjawisk społecznych, ale może przyczynić się do ich wyjaśnienia, dostarczając na przykład analizy semantycznej nazw tychże zjawisk. Badania Hermannsa objęły między innymi analizę znaczenia dyskursywnego takich terminów, jak: język, kultura, demokracja, globalizacja, terroryzm, środowisko, praca czy przytoczona wcześniej analiza wojny.

\section{Wnioski}

Holistyczna metoda interpretacji wypowiedzi językowych zaproponowana przez Hermannsa opiera się na przesłankach, które można sprowadzić do tezy Ludwiga Wittgensteina, że każde użycie języka, czy też każda gra językowa, funkcjonuje inaczej. Ponieważ konwencje społeczne regulują użycie języka tylko w ogólnym zarysie, wynikający stąd szkicowy, „niepełny” charakter wypowiedzi dopuszcza wiele ich interpretacji. Ponadto nie ma dwóch identycznych kontekstów tej samej wypowiedzi. Nawet wówczas, gdy poszczególne czynniki sytuacyjne pozostaną niezmienne, nastawienie użytkowników języka, czyli ich dyspozycja do działań językowych, ulega zmianom, które w nie mniejszym stopniu niż sama forma wypowiedzi wpływają na jej procesowanie.

W podejściu Hermannsa do problematyki znaczenia dyskursywnego można dostrzec także udaną próbę teoretycznego wyjaśnienia kontekstotwórczej roli uczestników danego dyskursu. Ich indywidualne kognicje, emocje i intencje mogą być komunikowane tylko dla-

${ }^{20}$ Taka koncepcja dyskursu została zaproponowana w tomie Busse, Hermanns, Teubert (Hrsg., 1994).

${ }^{21}$ Emocje i intencje powstają, tak jak kognicje, na podstawie społeczno-kulturowych wzorców działania (por. np. TAвакоwska, 1998; Wierzbicka, 1999; Fries, 2000; Manstaed, Frijda, Fischer, 2004). Odejście od tych wzorców może (chociaż nie musi) wiązać się z konsekwencjami, takimi jak: niezrozumienie wypowiedzi, utrata statusu społecznego, marginalizacja społeczna. 
tego, że są częścią ich wiedzy wspólnej, czyli istnieją i są uznawane („dzielone”) społecznie (wiem, że ty wiesz, i ty wiesz, że ja wiem). Również tzw. kontekst kulturowy wypowiedzi o tyle tylko odgrywa rolę $w$ procesie jej interpretacji, o ile jest reprezentowany $w$ strukturach tej wiedzy. Analiza dyskursu, która dąży do wyjaśnienia społecznych funkcji języka, nie może zatem ograniczać się - jak lingwistyka tekstu - do językowej analizy samego korpusu tekstów, lecz może i powinna obejmować analizę dyskursu jako zjawiska społecznego, a w szczególności analizować proces konstytuowania się wiedzy uczestników dyskursu. Metoda hermeneutyczna umożliwia wprawdzie jedynie częściowe dotarcie do warunków jej powstawania ${ }^{22}$, ale jest jak dotychczas jedyną metodą eksplikacji wiedzy kolektywnej.

Semantyka dyskursywna uprawiana za pomocą metody hermeneutycznej Hermannsa pozwala opisywać społeczno-kulturowy kontekst funkcjonowania języka już na poziomie analizy leksykalnej. Hermanns wyraża nawet przypuszczenie, że również lingwistyka dyskursywna bada go de facto tylko na tym poziomie, tj. badając nazwy zjawisk kulturowych. Lingwistycznie wyabstrahowane znaczenia tych nazw to nic innego, jak społecznie utrwalone kognicje, emocje i intencje. Jeśli Hermanns ma rację, uzasadnione jest twierdzenie, że deskryptywna analiza dyskursu może kontynuować tradycję szeroko rozumianej analizy filologicznej, która wpisuje się w filozoficzną tradycję hermeneutyczną.

\section{Literatura}

Bachmann-Medick D., 2012: Cultural Turns. Nowe kierunki w naukach o kulturze. Krzemieniowa K., tłum. Oficyna Naukowa. Warszawa.

BüHLER K., 1934: Sprachtheorie. Die Darstellungsfunktion der Sprache. Fischer Verlag. Jena.

Busse D., Hermanns F., Teubert W., Hrsg., 1994: Begriffsgeschichte und Diskursgeschichte. Methodenfragen und Forschungsergebnisse der historischen Semantik. Westdeutscher Verlag. Opladen.

FAlkenberg G., 1987: Ausdruck und Übernahme von Einstellungen. In: LiedtKe F., Keller R., Hrsg.: Kommunikation und Kooperation. Max Niemeyer. Tübingen, s. 159-181.

Fries N., 2000: Sprache und Emotionen. Ausführungen zum besseren Verständnis, Anregungen zum Nachdenken. Bastei Lübbe. Bergisch Gladbach.

GeERTz C., 2005: Wiedza lokalna. Dalsze eseje z zakresu antropologii interpretatywnej. WolsKA D., tłum. Wydawnictwo Uniwersytetu Jagiellońskiego. Kraków.

Grice H. P., 1975: Logic and Conversation. In: Cole P., Morgan J.L., eds.: Syntar and Semantics 3: Speech Acts. Academic Press. New York, s. 41-58.

Grochowskı M., 1997: Wyrażenia funkcyjne. Studium leksykograficzne. Instytut Języka Polskiego PAN. Kraków.

GruszczyńSKA E., 2001: Linguistic Images of Emotions in Translation from Polish into Swedish. Henryk Sienkiewicz as a Case in Point. Uppsala University. Uppsala.

Hermanns F., 1986: Appellfunktion und Wörterbuch. Ein lerikographischer Versuch. In: WIEGAND H.E. ed.: Studien zur neuhochdeutschen Lexikographie VI. Teil 1. Olms. Hildesheim-Zürich-New York, s. $151-182$.

Hermanns F., 1993a: Arbeit. Zur historischen Semantik eines kulturellen Schlüsselwortes. „Jahrbuch Deutsch als Fremdsprache“ 19, s. 43-62.

22 SPitzmüller, Warnke (2011: 184) podkreślają zresztą, że lingwistyczna analiza dyskursu w każdym przypadku umożliwia tylko egzemplaryczny dostęp do wiedzy dzielonej społecznie. 
Hermanns F., 1993b: Mit freundlichen Grüßen. Bemerkungen zum Geltungswandel einer kommunikativen Tugend. In: Klein W.P., Paul I., Hrsg: Sprachliche Aufmerksamkeit. Glossen und Marginalien zur Sprache der Gegenwart. Winter. Heidelberg, s. 81-85.

Hermanns F., 1994: Linguistische Anthropologie. Skizze eines Gegenstandsbereichs linguistischer Mentalitätsgeschichte. In: Busse D., Hermanns F., Teubert W., Hrsg.: Begriffsgeschichte und Diskursgeschichte. Methodenfragen und Forschungsergebnisse der historischen Semantik. Westdeutscher Verlag. Opladen, s. 29-59.

Hermanns F., 1995a: Kognition, Emotion, Intention. Dimensionen lerikalischer Semantik. In: HaRRAS G., Hrsg.: Die Ordnung der Wörter. Kognitive und lesikalische Strukturen. Walter de Gruyter. Berlin-New York, s. 138-178.

Hermanns F., 1995b: Sprachgeschichte als Mentalitätsgeschichte. Überlegungen zu Sinn und Form und Gegenstand historischer Semantik. In: Gardt A., Mattheier K.J., Reichmann O., Hrsg.: Sprachgeschichte des Neuhochdeutschen. Gegenstände, Methoden, Theorien. Max Niemeyer. Tübingen, s. 69-101.

HermanNS F., 1995c: „Deutsch“ und „Deutschland“. Zur Semantik deutscher nationaler Selbstbezeichnungswörter heute. In: JäGER L., Hrsg.: Disziplinäre Identität und kulturelle Leistung. Vorträge des deutschen Germanistentages 1994. Beltz Athenäum. Weinheim, s. 374-389.

Hermanns F., 1996: „Bombt die Mörder nieder!“ Überlegungen zu linguistischen Aspekten der Erzeugung von Gewaltbereitschaft. In: Diekmannshenke H., Klein J., Hrsg.: Wörter in der Politik. Analysen zur Lezemverwendung in der politischen Kommunikation. Westdeutscher Verlag. Opladen, s. $133-161$.

Hermanns F., 1999: Sprache, Kultur und Identität. Reflerionen über drei Totalitätsbegriffe. In: GARDT A., Hass-Zumkenr U., Roelcke T., Hrsg.: Sprachgeschichte als Kulturgeschichte. Walter de Gruyter. Berlin-New York, s. 351-391.

Hermanns F., 2002a: Dimensionen der Bedeutung I: Ein Überblick. In: Cruse D.A., HundsnurSCHeR F., Јов M., Lutzeier P.R., Hrsg.: Lexikologie. Ein internationales Handbuch zur Natur und Struktur von Wörtern und Wortschätzen. Bd. 21.1. Walter de Gruyter. Berlin-New York, s. 342-350.

Hermanns F., 2002b: Attitüde, Einstellung, Haltung. Empfehlung eines psychologischen Begriffs zu linguistischer Verwendung. In: Сневuвім D., Јаков K., Linке A., Hrsg.: Neue deutsche Sprachgeschichte, Mentalitäts-, kultur- und sozialgeschichtliche Zusammenhänge. Walter de Gruyter. Berlin-New York, s. 65-89.

Hermanns F., 2003: Die Globalisierung. Versuch der Darstellung des Bedeutungsspektrums der Bezeichnung. In: Wengeler M., Hrsg.: Deutsche Sprachgeschichte nach 1945. Diskurs- und kulturgeschichtliche Perspektiven. Beiträge zu einer Tagung anlässlich der Emeritierung Georg Stötzels. Маи Niemeyer. Hildesheim-New York, s. 131-137.

Hermanns F., 2005: „Krieg gegen den Terrorismus“. Über die Bedeutungen des Wortes Terrorismus im Diskurs der Medien und Experten. In: FraAs C., Klemm M., Hrsg.: Mediendiskurse. Bestandaufnahme und Perspektiven. Peter Lang. Frankfurt am Main, s. 142-168.

Hermanns F., 2007a: Diskurshermeneutik. In: WARnke I.H., Hrsg.: Diskurslinguistik nach Foucault. Theorie und Gegenstände. Walter de Gruyter. Berlin-New York, s. 187-210.

Hermanns F., 2007b: Empathie. Zu einem Grundbegriff der Hermeneutik. In: Hermanns F., Holly W., Hrsg.: Linguistische Hermeneutik. Theorie und Praxis des Verstehens und Interpretierens. Мах Niemeyer. Tübingen, s. 127-172.

Levinson S.C., 2000. Presumptive Meanings. The Theory of Generalized Conversational Implicature, Massachusetts Institute of Technology. London-Cambridge. 
LiedtKe F. 2007: Wie wir Fragmentarisches verstehen. In: Hermanns F., Holly W., Hrsg.: Linguistische Hermeneutik. Theorie und Pranis des Verstehens und Interpretierens. Mar Niemeyer. Tübingen, S. 59-99.

Manstaed A., Frijda N., Fischer A., 2004: Feelings and Emotions. The Amsterdam Symposium. Cambridge University Press. Cambridge.

Ryle G., 1971: Thinking and Reflecting. In: IDEM: Collected Papers. Vol. 2. Hutchinson. London, S. $480-496$.

Salovey P., Mayer J.D., 1990: Emotional Intelligence. „Imagination, Cognition and Personality“ IX, S. $185-211$.

Scherner M., 1984: Sprache als Teut. Ansätze zu einer sprachwissenschaftlich begründeten Theorie des Tertverstehens. Forschungsgeschichte - Problemstellung - Beschreibung. Маи Niemeyer. Tübingen. SchWARz-Friesel M., 2007: Sprache und Emotion. Gunter Narr. Tübingen-Basel.

SeARle J.R., 2010: Making the Social World. The Structure of Human Civilization. Orford University Press. Orford.

Spitzmüller J., Warnke I.H., 2011: Diskurslinguistik. Eine Einführung in Theorien und Methoden der transteatuellen Sprachanalyse. Walter de Gruyter. Berlin-Boston.

Tавакоwska E., 1998. Go to the Devil. Some Metaphors We Curse by. In: Athanasiadou A., TAвакошька E., eds.: Speaking of Emotions. Conceptualisation and Expression. Walter de Gruyter. Berlin-New York, s. 253-269.

TOPCZEWSKA U., 2011: Lingwistyczne modelowanie procesu rozumienia tekstu. „Biuletyn Polskiego Towarzystwa Językoznawczego" LXVII, s. 185-194.

Wierzbicka A., 1991: Cross-cultural Pragmatics. The Semantics of Human Interaction. Walter de Gruyter. Berlin-New York.

WierzBickA A., 1999: Emotions across Languages and Cultures. Diversity and Universals. Cambridge University Press. Cambridge.

Wittgenstein L., 1971: Philosophische Untersuchungen. Suhrkamp Verlag. Frankfurt am Main.

Ziem A., 2008: Frames und sprachliches Wissen. Kognitive Aspekte der semantischen Kompetenz. Walter de Gruyter. Berlin-New York. 